\title{
MEMOTRET BENTUK-BENTUK TOLERANSI DI DESA KAMPUNG KUSAMBA, KARANGASEM, BALI
}

\section{Capturing the Shapes of \\ Tolerance in Kampung Kusamba Village, Karangasem, Bali}

\author{
Naniek Kohdrata \\ Program Studi Arsitektur Lanskap, \\ Fakultas Pertanian, Univesitas Udayana \\ Email: naniek_kohdrata@unud.ac.id \\ Cokorda Gede Alit Semarajaya \\ Program Studi Arsitektur Lanskap, \\ Fakultas Pertanian, Univesitas Udayana \\ Email: coksemarajaya@unud.ac.id
}

\section{ABSTRACT}

Kampung Kusamba Village is a relatively small size village in the Bali Island with a majority Muslim population. The village area is surrounded by villages that are predominantly Hindu. The Kampung Kusamba is an example that tolerance in social life is actualized. This research emphasizes on documenting tolerance between Kampung Kusamba dwellers with the Balinese through architectural forms and folklores, myths, or any other oral histories. The research method used is qualitative. Data were collected using a purposive approach, utilizing an in-depth interview technique to resource persons and photographic surveyed for architectural forms. The analysis was carried out descriptively using an ethnographic domain analysis technique approach. Preliminary findings from this study were that physical architectural features that reflect the local culture are the same or almost the same as Balinese architecture. A form of tolerance was also found in the form of artifacts that reflected the diversity of the population of Kampung Kusamba in the past. Oral histories of the past as a manifestation of the intangible landscape also showed the attitude and tolerance of the people of Kampung Kusamba and the people who live in Bali respectively. Moreover, there was also a story that shows the position and special relationship of Kampung Kusamba with Klungkung Royal.

Keywords: architecture of tolerance, Balinese Moslem, Kampung Kusamba

\section{PENDAHULUAN}

Teknologi dan informasi yang berkembang pesat saat ini telah banyak memberikan kontribusi positif pada kualitas kehidupan manusia. Namun, pada saat bersamaan muncul juga pengaruh negatif dari kemajuan teknologi dan informasi tersebut. Salah satu fenomena yang saat ini sedang marak adalah sikap intoleransi yang terjadi pada sebagian masyarakat Indonesia. Ketua Satgas Nusantara, Irjen (Pol) Gatot Eddy Pramono dalam berita yang dimuat di media daring Kompas, menyebutkan tiga hal yang menyebabkan meningkatnya sikap intoleransi di antara masyarakat Indonesia. Ketiga hal tersebut adalah pertama, globalisasi yang menggerus nilai-nilai ketimuran, kedua bahwa iklim demokrasi di Indonesia belum ideal karena masih didominasi masyarakat yang secara pendidikan, ekonomi, dan beberapa aspek lain masih lemah, dan ketiga adalah perkembangan media sosial yang pesat sehingga berdampak pula pada penyebaran paham intoleran dengan kecepatan yang sama (Nugraheny, 2019). Derasnya informasi yang bersifat tendensius maupun informasi yang salah telah mencabik-cabik jalinan bermasyarakat saling menghormati dan menghargai yang sebenarnya telah terbentuk di bumi nusantara.

Desa Kampung Kusamba dikenal sebagai desa yang mayoritas penduduknya adalah Islam. Wilayah desa tersebut berada di antara wilayah desa lain dengan mayoritas penduduknya Hindu. Posisi Desa Kampung Kusamba terhadap wilayah desa lain, yaitu Desa Kusamba dan Selat Badung jika dilihat secara geografis menyerupai pola enclave. Sebuah enclave secara teoritis dicirikan dengan adanya perbedaan kondisi penghuni habitat tersebut dengan lingkungan sekitarnya (RozhkovYuryevsky, 2013). Kasus Desa Kampung Kusamba memiliki keunikan tersendiri, yaitu secara kewilayahan mempunyai ciri pola ruang seperti enclave, akan tetapi perbedaan yang dimiliki masyarakat desa tersebut secara nyata hanya pada agama yang dianut, yaitu Islam. Sementara aspek kehidupan dan ciri-ciri budaya lain hampir sama dengan masyarakat yang tinggal di Desa Kusamba, yaitu kehidupan sehari-hari yang bernafaskan budaya Bali (Parimartha et al, 2012). Salah satu bentuk toleransi sosial dalam balutan lanskap budaya tersebut dapat dijumpai di Desa Kampung Kusamba, Kabupaten Klungkung.

Ditengah-tengah berbagai bentuk intoleransi yang muncul, Desa Kampung Kusamba dapat menjadi salah satu contoh bagi masyarakat Indonesia khususnya dan dunia pada umumnya bahwa toleransi dalam kehidupan bermasyarakat adalah nyata. Lanskap budaya yang telah terbentuk dalam keseharian masyarakat Desa Kampung Kusamba perlu didokumentasikan untuk kemudian didiseminasikan kepada publik sebagai suatu pembelajaran. Warisan lanskap budaya yang baik ini perlu diketahui dan dipahami terutama oleh generasi muda Indonesia dan Bali khususnya. Nilai-nilai kemanusian yang bersifat universal dan sekaligus kearifan lokal nusantara yang terpatri dalam lanskap budaya Kampung Kusamba patut dilestarikan. Wujud pluralisme nyata dalam skala mikro yang baik sebagai pembelajaran bagi generasi penerus bangsa yang berkarakter Pancasila.

Penelitian ini merupakan upaya pencarian dan penelusuran kembali jejak-jejak lanskap budaya hasil interaksi masyarakat setempat dengan lingkunganya. Interaksi masyarakat dengan lingkungan yang bersifat fisik dan non-fisik telah menghasilkan lanskap budaya Desa Kampung Kusamba dengan ciri-ciri yang unik dan bernilai kemanusiaan tinggi. Hal ini sejalan dengan pendapat Awalia et al. (2017) yang mengatakan bahwa komponen fisik (tangible) dan non-fisik (intangible) berperan dalam proses pembentukan lanskap budaya. 
Ciri-ciri fisik arsitektural yang dimiliki oleh Kampung Kusamba saat ini mulai menghilang (Yuantoro, 2018). Sejalan dengan dinamika kehidupan masyarakat, maka bentuk-bentuk arsitektural relatif rentan berubah sesuai dengan usia struktur, perkembangan pengetahuan, teknologi, material, dan juga kecenderungan gaya desain arsitektural (Salain, 2015). Jaman yang berubah tentu berdampak pula pada sejumlah arsitektur bangunan di Kampung Kusamba. Oleh karena itu penting untuk didokumentasikan bentuk-bentuk arsitektural yang pernah ada sebagai bahan pengetahuan dan pembelajaran. Sementara ciri-ciri unik elemen lanskap yang bersifat intangible seperti adat kebiasaan, cerita rakyat (folklore), atau hal-hal yang bersifat kesejarahan setempat dicatat sebagai dokumentasi untuk dikemudian hari dapat dilakukan pendalaman

\section{METODE PENELITIAN}

Penelitian dilakukan di Desa Kampung Kusamba yang berada di Kabupaten Klungkung, Bali. (Gambar 1). Studi yang dilakukan di Desa Kampung Kusamba merupakan penelitian deskriptif-kualitatif. Tahapan penelitian dimulai dari pengumpulan data melalui prosedur purposif Burhan Bungin (Bungin, 2017). Prosedur purposif yang dimaksud adalah pemilihan informan dilakukan berdasarkan kriteria tertentu yang relevan dengan tujuan penelitan. Pada penelitian ini, kriteria yang diperlukan untuk menjadi informan adalah 1) tinggal di wilayah penelitian minimal 30 tahun, 2) lahir atau memiliki orang tua yang berasal dari lokasi penelitian, 3) pernah atau sedang menduduki jabatan struktural administratif di lokasi, 4) tetua masyarakat adat setempat atau tokoh bagi masyarakat setempat. Ukuran sampel akan ditentukan berdasarkan teori kejenuhan, yaitu saat informasi dari para informan tidak lagi memberikan data baru yang memberikan wawasan tambahan dari pertanyaan yang diajukan peneliti. Teknik wawancara yang dilakukan adalah wawancara bertahap. Teknik ini memungkinkan wawancara dilakukan secara terarah namun tetap bebas dan mendalam (in-depth) tanpa lepas dari pokok permasalahan yang ditanyakan pada responden.

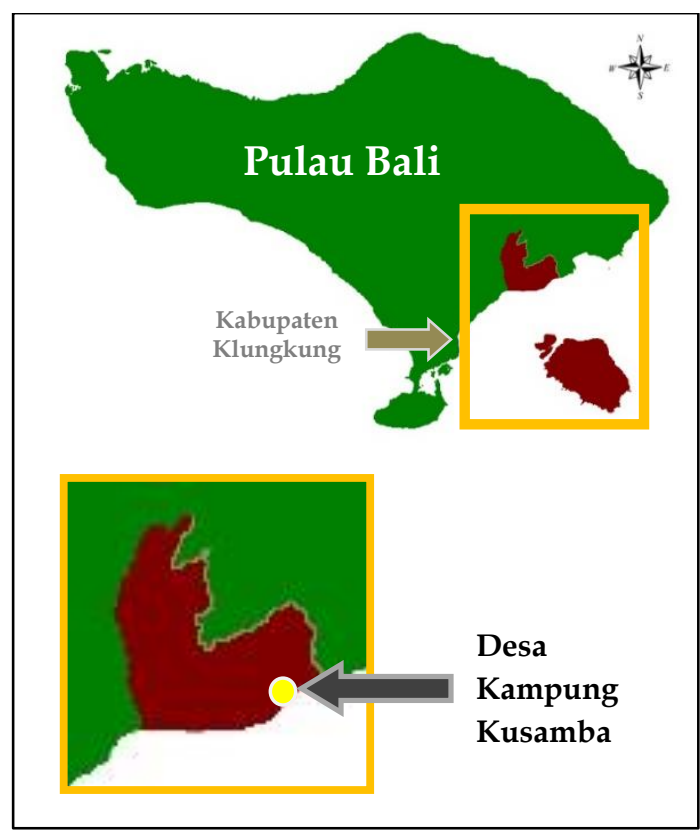

Gambar 1. Peta Orientasi Lokasi Penelitian
Teknik analisis yang digunakan pada penelitian ini dilakukan secara deskriptif. Metode analisis tersebut memungkinkan penarasian suatu objek secara kontekstual dan tidak mendalam. Hal ini sesuai dengan tujuan penelitian yang masih bersifat eksploratif. Hasil dari penelitian ini merupakan bagian dari penelitian selanjutnya.

\section{HASIL DAN PEMBAHASAN}

\section{Wilayah Administrasi dan Kondisi Umum}

Desa Kampung Kusamba merupakan sebuah desa yang secara administratif terletak di Kecamatan Dawan, Kabupaten Klungkung, Provinsi Bali. Kampung Kusamba memiliki luas wilayah 10 hektar dan terletak pada ketinggian 0-15 meter di atas permukaan laut. Kepadatan penduduk Desa Kampung Kusamba pada tahun 2016 mencapai 6.900 jiwa $/ \mathrm{km}^{2}$. Desa ini terletak kurang lebih 3 km dari ibu kota Kecamatan Dawan dan 7 km dari ibu kota Kabupaten Klungkung. Secara geografis Desa Kampung Kusamba terletak pada $8^{\circ} 33^{\prime} 50^{\prime \prime}$ LS dan $115^{\circ} 27^{\prime} 7^{\prime \prime}$ BT (BPS Kabupaten Klungkung, 2017).

Penggunaan lahan dengan luas 10 hektar di Desa Kampung Kusamba berdasarkan manfaat dan kebutuhan masyarakat dapat dibagi menjadi tiga, yakni tanah perumahan seluas 3,2 Ha, tanah tegalan (perkebunan) seluas 3,1 Ha, fasilitas umum, perkantoran dan lain-lain seluas 3,7 Ha. Kondisi alam Desa Kampung Kusamba yang merupakan daerah pesisir menyebabkan sebagian besar penduduk memanfaatkan lahan sebagai perumahan dan fasilitas umum.

Posisi geografis Desa Kampung Kusamba dikelilingi oleh Desam Kusamba dan Selat Badung (Gambar 2). Kondisi ini membuat pola tata ruang Desa Kampung Kusamba terhadap Desa Kusamba menyerupai enclave. Wilayah kepemilikan Kampung Kusamba memenuhi kriteria definisi enclave seperti disebut oleh Rozhkov (2013), yaitu sebidang lahan kecil yang terletak "di dalam" lahan milik yang lain.

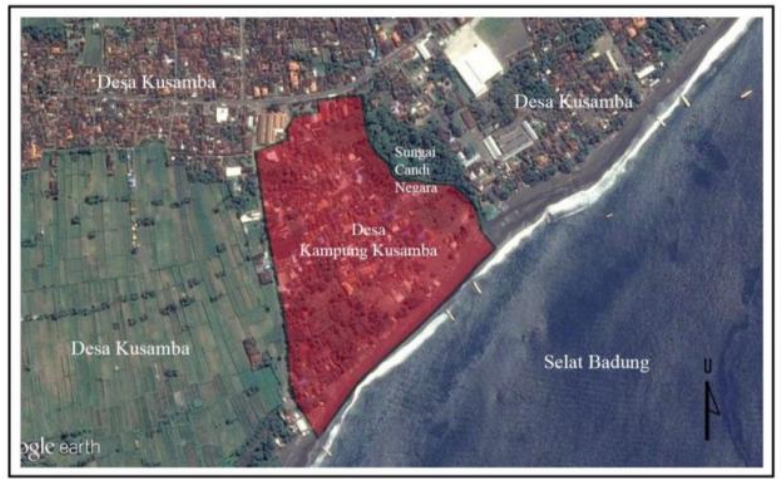

Gambar 2. Peta Posisi Desa Kampung Kusamba

\section{Demografi Masyarakat}

Desa Kampung Kusamba merupakan desa dengan kepadatan penduduk pada tahun 2016 mencapai 6.900 jiwa $/ \mathrm{km}^{2}$. Menurut data dalam Laporan Keterangan Pertanggungjawaban (LKPJ) Akhir Tahun 2016 Desa Kampung Kusamba, desa ini memiliki jumlah penduduk sebanyak 690 jiwa pada tahun 2016 yang terhimpun dalam 190 KK (Tim Penyusun LKPJ, 2016). 
Desa Kampung Kusamba dikenal sebagai salah satu kampung Islam di Kabupaten Klungkung. Julukan tersebut diberikan karena mayoritas masyarakatnya memeluk agama Islam, yaitu sebesar 98,6\%, sedangkan sebesar 1,4\% lainnya memeluk agama Kristen. Keunikan lain adalah walaupun mayoritas penduduk di Bali memeluk agama Hindu, namun di Kampung Kusamba sama sekali tidak terdapat penduduk yang beragama Hindu. Padahal secara kewilayahan desa ini berbatasan dengan Desa Kusamba yang mayoritas penduduknya beragama Hindu. Rincian mengenai agama yang dianut oleh penduduk Desa Kampung Kusamba pada tahun 2016 ditampilkan pada Tabel 1.

Tabel 1. Jumlah Penduduk Berdasarkan Agama

\begin{tabular}{cc}
\hline Agama & Jumlah Penganut \\
\hline Islam & 680 \\
Budha & 0 \\
Kristen & 10 \\
Hindu & 0 \\
\hline Total & $\mathbf{6 9 0}$
\end{tabular}

Sumber: Desa Kampung Kusamba (2016)

Meskipun demikian Desa Kampung Kusamba bukanlah Kampung Islam yang terisolasi. Menurut salah seorang informan peneliti, pernikahan antara individu dengan latar belakang agama yang berbeda adalah hal biasa. Pernikahan antara warga Kampung Kusamba yang beragama Islam dengan warga dari Desa Kusamba yang Hindu adalah lumrah. Demikian pula pasangan tersebut kemudian akan menentukan keyakinan yang dipilih sebagai keluarga baru.

Parimartha (2012) mengatakan bahwa warga Kampung Kusamba merupakan komunitas muslim yang berbeda dengan warga desa adat Hindu. Perbedaan yang dimaksud Parimartha adalah pada jaman dahulu Kerajaan Klungkung telah memberikan perlindungan dan pengakuan khusus kepada warga Kampung Kusamba sebagai entitas yang berdaulat dalam menjalankan keyakinan, budaya, dan tradisinya.

\section{Sejarah Desa Kampung Kusamba}

\section{Sejarah Keberadaan Kampung Kusamba}

Kisah awal mula keberadaan Kampung Kusamba memiliki alur sejarah yang kurang lebih sama dengan kampung-kampung Islam yang ada di Bali, yaitu diawali oleh kedatangan para perantau dari Bugis dan Jawa. Para perantau tersebut kemudian dalam prosesnya mendapat perlindungan dan juga sekaligus wilayah permukiman dari para penguasa di Bali. Menurut sejarah, para penguasa tersebut segaja menempatkan mereka ke dalam wilayah permukiman yang terpisah dengan warga Bali yang beragama Hindu. Wilayah tersebut umumnya wilayah baru yang sebelumnya hutan, atau wilayah pesisir yang dekat dengan pelabuhan.

Menurut Parimartha (2012) terdapat beberapa versi sejarah lisan terkait dengan asal-usul perantau yang membentuk Kampung Kusamba. Versi pertama menyebutkan bahwa para perantau tersebut adalah keturunan Bugis yang diberi tanah oleh Raja Klungkung. Pemberian tanah wilayah tersebut sebagai bentuk penghargaan dan terima kasih Raja terhadap jasa-jasa orang Bugis dalam membantu Kerajaan Klungkung dalam berbagai hal seperti pengobatan, kelautan dan perdagangan. Versi kedua adalah para perantau yang datang ke Kusamba memiliki ikatan silsilah dengan perantau Muslim yang ada di Kampung Gelgel di Klungkung. Sejarah versi ini meyakini bahwa ada hubungan antara warga Muslim di Kampung Gelgel dengan warga Muslim di Kusamba. Versi ini juga menyebutkan bahwa warga Muslim dari Kampung Gelgel pindah ke Kampung Lebah Klungkung, kemudian pindah lagi ke Kampung Kusamba. Berdasarkan versi ini dapat diperkirakan bahwa penganut Islam sudah masuk Desa Kusamba paling tidak pada abad ke-16 ketika Kampung Gelgel telah berdiri.

Desa Kampung Kusamba memiliki dua objek sejarah dari kehadiran umat Muslim di tempat tersebut. Objek pertama adalah sebuah makam tua yang dikeramatkan dan kelilingi sejumlah makam-makam kuno lain. Makammakam kuno tersebut memiliki ciri khas berupa nisan yang terbuat dari batu yang diukir dengan ornamen unik berbentuk sulur dan bunga. Berada di antara makammakam kuno berornamen unik, terdapat satu makam yang dikeramatkan warga. Pada awalnya makam tersebut sama seperti makam lainnya, namun pada tahun 1995 makam ini dipugar oleh keluarga Abdul Gani dan dibuatkan kijing dari keramik dengan tujuan memperkuat struktur yang ada sebelumnya.

Objek kedua adalah makam yang diyakini oleh warga sebagai makam seorang habib, yakni Habib Ali bin Abubakar al Hamid. Menurut tokoh masyarakat Kampung Kusamba dalam Parimartha (2012), semasa hidupnya Habib Ali dikenal sebagai penerjemah atau ahli bahasa yang bertugas mengajarkan bahasa melayu kepada Raja Dewa Agung Jambe. Namun, kedekatan Habib Ali dengan Raja Dewa Agung Jambe akhirnya menuai petaka karena Habib Ali merupakan seorang Muslim yang memiliki keyakinan berbeda dengan keyakinan mayoritas warga kerajaan. Konon menurut cerita, suatu hari seusai menghadap Raja Klungkung, Habib Ali sedang dalam perjalanan kembali ke Kampung Kusamba. Di tengah perjalanan ia dihadang oleh sekelompok orang tidak dikenal yang menyerangnya hingga meninggal. Konon penyerangan itu terjadi karena salah pengertian dengan warga di desa yang dilalui Habib Ali. Peristiwa meninggalnya Habib Ali didengar oleh Raja Klungkung. Sang raja pun memerintahkan prajurit kerajaan untuk memakamkan jasad Habib Ali di tepi Pantai Kusamba, tempat beliau wafat. Berawal dari kisah inilah kemudian diyakini bahwa makam keramat tersebut adalah makam seorang habib.

Versi lain dari sejarah makam keramat tersebut adalah bahwa makam itu bukan makam seorang Habib, melainkan makam Mbah Samba. Oleh masyarakat setempat, Mbah Samba dipercaya merupakan tetua yang cikal bakal Kampung Kusamba. Versi ini menyebutkan bahwa makam tersebut berusia lebih tua dari versi pertama. Versi ini meyakini bahwa makam Mbah Samba dibangun pada abad 14 Masehi kurang lebih pada masa pemerintahan Kerajaan Gelgel atau sebelum berdirinya Kerajaan Klungkung

\section{Asal-usul nama Kampung Kusamba}

Menurut penelitian yang dilakukan oleh Yuantoro (2018) sejarah nama Desa Kampung Kusamba berawal dari cerita rakyat (folkore) dalam masyarakat desa tersebut. Konon asal muasal nama Kusamba bersumber dari sebuah dialog 
antara seorang Suku Bugis dengan seorang Suku Banjar. Ketika itu orang Bugis tersebut melaksanakan sholat yang kemudian menjadi perhatian orang Banjar. Setelah selesai sholat, orang Banjar tersebut mendekat dan bertanya kepada orang Bugis "Agamamu apa?" kemudian orang Bugis tersebut menjawab "Saya Islam". Orang Bugis tersebut kemudian berbalik tanya "Agamamu apa?" lalu dijawab kembali oleh orang Banjar tersebut "Aku sama". Kata [a]ku sama inilah yang menurut cerita menjadi cikal bakal nama kampung Kusamba. Kata "kampung" pada masyarakat Bali merupakan ungkapan untuk menyatakan bahwa daerah tersebut merupakan kantong-kantong masyarakat Muslim. Maka desa inipun dikenal sebagai Desa Kampung Kusamba.

\section{Arsitektural Kampung Kusamba}

Saat pengambilan data penelitian, masih terlihat beberapa bangunan tempat tinggal masyarakat Kampung Kusamba dengan ciri arsitektural dekoratif yang cukup umum dijumpai pada rumah-rumah dengan arsitektur tradisional Bali (Gambar 3). Unsur dekoratif tersebut dijumpai pada bagian atap dan juga bentuk arsitektur pintu pagar rumah beberapa penduduk.
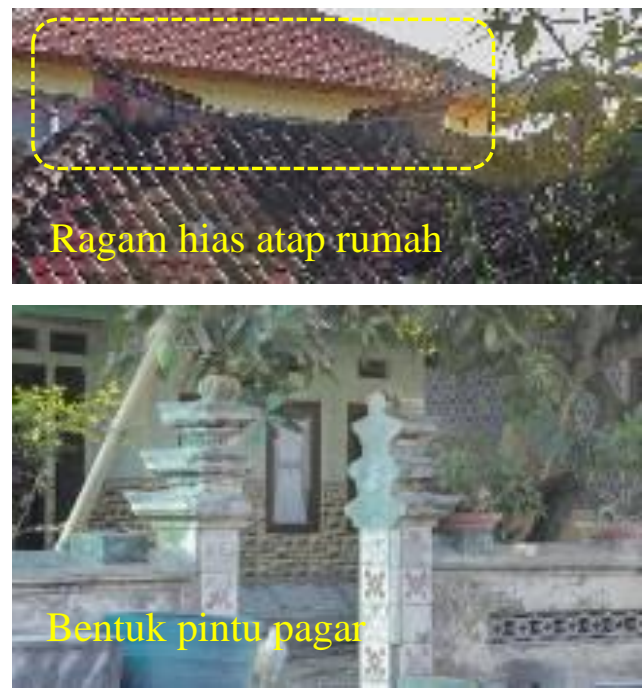

Gambar 3. Ragam Hias Rumah Tinggal

Bangunan peribadatan masyarakat Kampung Kusamba, yaitu Masjid Al-Mahdi juga menunjukkan adanya sejumlah ciri arsitektural banguan Bali. Minaret atau menara masjid berwujud seperti bangunan tumpang tiga dan dikombinasikan dengan bentuk kubah di bagian puncaknya (Gambar 4). Bentuk tersebut mirip dengan struktur meru pada bangunan di pura-pura Bali.

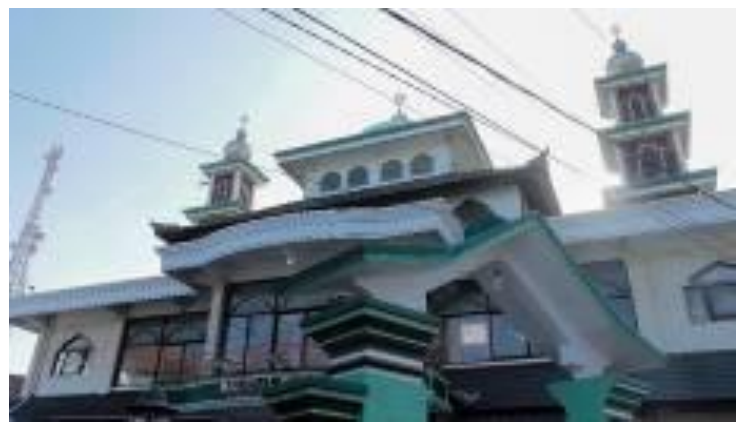

Gambar 4. Ragam Hias Rumah Tinggal
Bentuk arsitektural yang muncul di Desa Kampung Kusamba merupakan hasil dari proses panjang interaksi masyarakat Kampung Kusamba dan masyarakat Bali pada umumnya dalam konteks kebudayaan. Di Kampung Kusamba terjadi pertemuan budaya dan sekaligus terbangunnya toleransi antar masyarakat pemeluk keyakinan berbeda yang terwujud dalam bentuk arsitektural. Hal ini sejalan dengan pendapat Mazilu dan Lazar (2014) bahwa lanskap budaya memberikan kontribusi pada identitas lokal dan regional, serta mencerminkan sejarah dan interaksi antara manusia dengan alam. Ciri-ciri tersebut dapat ditemukan dalam kehidupan masyarakat dan juga arsitektur bangunan di Kampung Kusamba.

Desa Kampung Kusamba juga terkenal dengan adanya makam Habib Ali bin Abu Bakar Umar Al Hamid. Sebuah patung yang menggambarkan Habib Ali sebagai seorang lelaki bersorban mengenakan pakaian putih sedang menunggang kuda putih menjadi penanda dari keberadaan makam tersebut (Gambar 5). Simbol patung dibangun sebagai perlambang karena diyakini pada masa dulu Habib Ali mengendarai kuda putih. Patung tersebut dibangun atas inisiatif masyarakat untuk mengilustrasikan beliau. Menurut Samsul (2019), inisiatif pembuatan patung tersebut adalah warga Kampung Kusamba, sementara pengerjaannya dilakukan oleh tukang dari Desa Kusamba.

Makam Habib Ali bin Abu Bakar Umar al Hamid saat ini berada dalam satu bangunan dengan dua pintu yang terletak di sisi sebelah utara dan sebuah pintu lain di sisi timur bangunan. Kedua pintu akses tersebut menggunakan pintu dengan model ukiran Bali (Gambar 6). Demikian pula jika diamati dinding bangunan di sekeliling makam tersebut lebih menyerupai pagar penyengker seperti umumnya pagar yang dapat dijumpai pada bangunan tradisional masyarakat Bali.

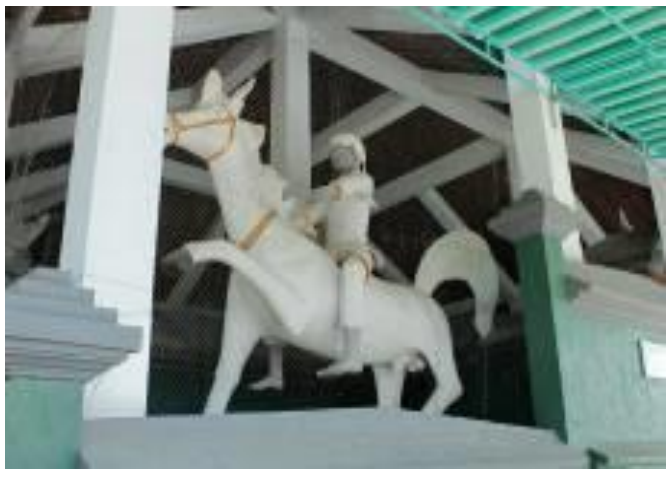

Gambar 5. Patung Habib Ali

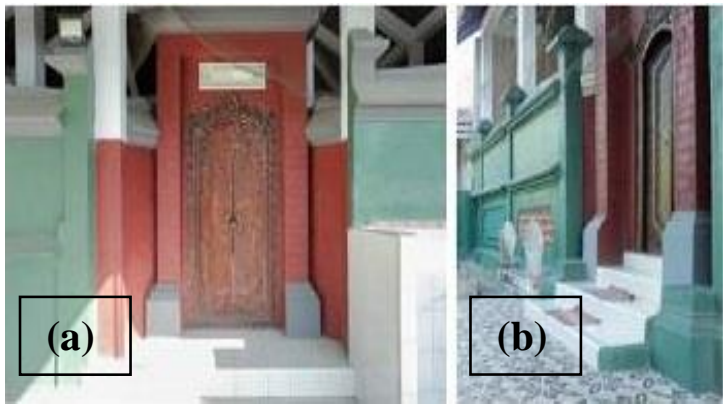

Gambar 6. Arsitekural luar makam Habib Ali bin Abu Bakar Umar Al Hamid 
Informasi dari narasumber mengatakan bahwa pada masa lampau, makam tersebut berada di luar ruang (outdoor). Namun dikemudian hari dibuatlah semacam atap pelindung sehingga peziarah bisa lebih nyaman saat berkunjung menziarahi makam. Sejalan dengan waktu dilakukan penambahan struktur berupa tembok yang mengelilingi makam untuk ketertiban dan kenyamanan peziarah.

Selain makam Islam, di Kampung Kusamba juga dijumpai makam Cina. Informasi yang didapat di lapang dari narasumber (Samsul, 2019) mengatakan bahwa saat ini keluarga pemilik makam Cina di Kampung Kusamba sudah tidak menetap lagi di sana. Namun ada keturunannya yang menetap di Desa Kusamba dan beberapa lainnya tersebar di daerah pulau Bali lainnya. Sekali setahun keluarga dari pemilik makam datang membersihkan makam dan berziarah. Pengamatan di lapang mengindikasikan bahwa yang dimakamkan di area tersebut berasal dari satu keluarga atau setidaknya berasal dari satu marga. Beberapa nisan yang masih terbaca tulisan informasi almarhum yang dimakamkan menunjukkan marga Yap yang disertai juga dengan nama khas Bali yang dimiliki almarhum seperti N.W. Rungu, Pt. Mudayana, dan beberapa nama lain yang menunjukkan keturunannya (Gambar 7).
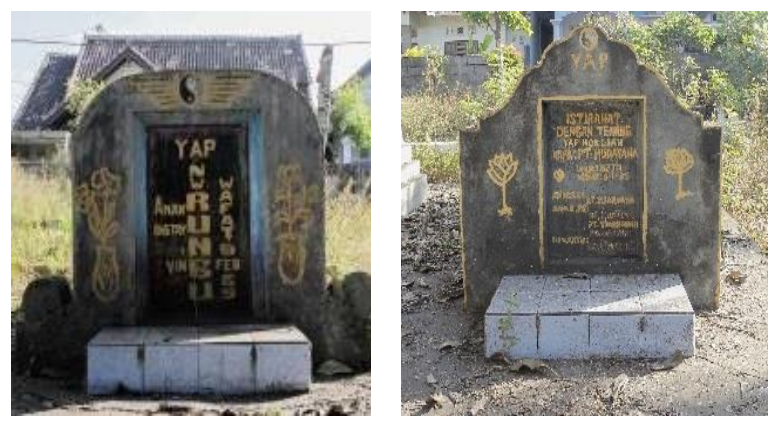

Gambar 7. Makam Cina di Kampung Kusamba

Sekilas dapat dikatakan bahwa makam-makam yang pada Gambar 7 menunjukkan bentuk umum arsitektural nisan makam seperti makam Cina yang dijumpai di beberapa pulau besar Indonesia.

\section{Legenda Cerita Habib Ali di Kampung Kusamba}

Cerita tentang Habib Ali didapat dari dua orang informan, yaitu Hambali dan Samsul - tokoh masyarakat di Kampung Kusamba. Penyampaian cerita legenda tersebut dilakukan secara turun temurun melalui lisan di antara masyarakat. Konon dikisahkan bahwa Habib Ali adalah seorang penasihat raja Klungkung. Sebagai penasihat dan "guru" tentang kemaritiman maka Habib Ali mendapat fasilitas kendaraan seekor kuda putih. Diceritakan pada suatu hari dalam perjalanan kembali dari Puri Klungkung, setelah menghadap Raja Klungkung, Habib Ali kembali ke Kusamba dengan menunggang kuda putihnya melewati Puri Kusamba. Saat melewati puri, ia tidak turun dari atas kuda karena ia adalah punggawa raja. Pada masa itu, masyarakat biasa yang sedang berada di atas hewan tunggangan akan melintas di depan puri yang merupakan tempat tinggal raja atau kaum bangsawan, maka mereka wajib untuk turun dari tunggangannya. Status Habib Ali yang merupakan punggawa raja rupanya tidak diketahui oleh penghuni puri Kusamba yang kebetulan melihat ia melintas. Para bangsawan puri tersebut merasa dilecehkan dengan tidak turunnya Habib Ali dari kudanya. Dicemetilah kuda putih yang ditunggangi Habib Ali hingga kuda tersebut panik, melonjak-lonjak dan melesat tak terkendali. Setelah kuda berhasil dikendalikan maka kembalilah Habib Ali pada sekelompok orang yang mencemeti kudanya tadi. Dikisahkan terjadi pertengkaran dan kemudian perkelahian hingga Habib Ali terbunuh. Jenazah Habib Ali akhirnya dimakamkan oleh seorang punggawa dari Kusamba. Punggawa tersebut meminta ijin untuk memakamkan Habib Ali di Kampung Kusamba karena ia memiliki agama yang sama dengannya. Sementara masyarakat di Kusamba saat itu tidak berani melakukan pemakaman karena perbedaan kepercayaan. Demikian menurut penuturan dari dua orang narasumber di Desa Kampung Kusamba (Hambali, 2018; Samsul, 2019).

\section{SIMPULAN}

Hasil yang dapat disimpulkan dari studi awal tentang peninggalan bentuk arsitektural dan lanskap di Desa Kampung Kusamba menunjukkan bahwa masyarakat telah bertoleransi bahkan sejak masa lampau. Bentukan arsitektural yang tercermin dari façade rumah tinggal dan juga masjid Al-Mahdi membuktikan bagaimana masyarakat Kampung Kusamba bermasyarakat sejak dulu. Demikian pula dari pihak Puri Klungkung juga menunjukkan penerimaan dan toleransi dengan menghibahkan wilayah desa kepada penduduk Kampung Kusamba.

Cerita-cerita yang diturunkan dari para tetua masyarakat Kusamba juga menyiratkan semangat toleransi dan kebersamaan sebagai manusia Bali. Konsep menyama braya tumbuh, berkembang, dan diwariskan dari generasi ke generasi. Terutama cerita mengenai Habib Ali bin Abu Bakar Umar Al Hamid yang seyogyanya diambil hikmah untuk menumbuhkan dan memelihara kebersamaan dan rasa persaudaraan.

Studi ini belum membahas secara teoritis hasil temuan arsitektural dan juga data lanskap tak benda yang ada di Kampung Kusamba. Masih terbuka peluang untuk menginterpretasikan data yang ditemukan dari penelitian ini. Demikian pula masih terbuka kesempatan melakukan penggalian informasi lebih lanjut dari aspek-aspek lanskap budaya yang ada di Kampung Kusamba.

\section{UCAPAN TERIMA KASIH}

Penulis mengucapkan terima kasih atas pendanaan penelitian yang diberikan oleh Universitas Udayana melalui Hibah Penelitian Unggulan Program Studi sebagaimana yang tertuang dalam Surat Perjanjian Kerja (SPK) Nomor: 1204/UN14.2.6.II/LT/2019.

\section{DAFTAR PUSTAKA}

BPS Kabupaten Klungkung. 2017. Kecamatan Dawan Dalam Angka 2017. Retrieved from Badan Pusat Statistik Kabupaten Klungkung website: https://www.m-culture.go.th/mculture_th/ download/king9/Glossary_about_HM_King_Bhu mibol_Adulyadej's_Funeral.pdf

Bungin, B. 2017. Penelitian Kualitatif: komunikasi, ekonomi, kebijakan publik, dan ilmu sosial lainnya (2nd ed.). Jakarta: Kencana. 
Hambali. 2018. Wawancara tahun 2018. Klungkung, Bali.

Mazilu, M., Lazar, I. 2014. The Cultural Landscape: Perception, Knowledge, Awareness and Support to The Development of a Sustainable Tourism. Geopolitics, History, and International Relations, 6(1), 123-132.

Nugraheny, D.E. 2019. Ini Tiga Sebab Menguatnya Sikap Intoleransi di Indonesia Versi Polri. Kompas.Com. Retrieved from https://nasional.kompas.com/ $\mathrm{read} / 2019 / 11 / 16 / 07364551 /$ ini-tiga-sebab-

menguatnya-sikap-intoleransi-di-indonesia-versipolri?page $=$ all

Awalia, N.R., Nurhayati, Kaswanto, R.L. 2017. Kajian Karakter Pembentuk Lanskap Budaya Masyarakat Adat Kajang Di Sulawesi Selatan. Jurnal Lanskap Indonesia, 9(2), 91-100. https://doi.org/10.29244/ jli.2017.9.2.91-100

Parimartha, I.G., Putra, I.B.G., Ririen, L.P.K. 2012. BULAN SABIT DI PULAU DEWATA Jejak Kampung Islam Kusamba-Bali (A. A. Dwipayana, Ed.). Yogyakarta: Program Studi Agama dan Lintas Budaya (Center for Religious and Cross-cultural Studies/CRCS) Sekolah Pascasarjana, Universitas Gadjah Mada.

Rozhkov-Yuryevsky, Y. 2013. The concepts of enclave and exclave and their use in the political and geographical characteristic of the Kaliningrad region. Baltic Region, 2(2), 113-123. https:/ / doi.org/ 10.5922/2079-8555-2013-2-11

Salain, P.R. 2015. Sebuah Pengalaman Konservasi Taman Sukasada - Ujung Karangasem sebagai Taman Air Terbesar dan Termegah di Bali. In G. M. A. Suartika \& I. K. Pranajaya (Eds.), 25 Karya Arsitek IAI Bali dan IAA Universitas Udayana (pp. 156-167). Denpasar: Ikatan Arsitek Indonesia (IAI) Bali dan Ikatan Alumni Arsitektur (IAA) Universitas Udayana.

Samsul. 2019. Wawancara bulan Juli 2019. Klungkung, Bali.

Tim Penyusun LKPJ. 2016. Laporan Keterangan Pertanggungjawaban (LKPJ) Akhir Tahun 2016 Desa Kampung Kusamba. Klungkung, Bali.

Yuantoro, S. 2018. Identifikasi Lanskap Vernakular di Desa Kampung Kusamba, Klungkung. Udayana. 